\title{
DASH Diet Quality and Status of Mental Emotional Disorder among Hypertensive Women in Rural Area
}

\author{
Diajeng Rochma Islami ${ }^{1,2}$, Ikeu Tanziha ${ }^{1 *}$, Drajat Martianto ${ }^{1}$, \\ Purnawati Hustina Rachman ${ }^{1}$ \\ ${ }^{1}$ Department of Community Nutrition, Faculty of Human Ecology, IPB University, Bogor 16680, Indonesia \\ ${ }^{2}$ Food Security Agency, Ministry of Agriculture Indonesia, Jakarta 12550, Indonesia
}

\begin{abstract}
The purpose of this study was to analyse the relationship between diet quality and mental emotional disorder status with the incidence of hypertension in women in rural areas. The study was a cross sectional study with 143 women (71 with normotensive and and 72 with hypertension) in Pondok Bungur Village, Purwakarta District, West Java, Indonesia. The independent variables were dietary qualities based on customized DASH-like diet and mental emotional disorder status, while the dependent variable was hypertension status. Dietary quality was obtained by non consecutive 2 days 24 hours recall, while mental emotional disorder was collected through SRQ 20. Chi-Square and Mann-Whitney were used for data analysis. The DASH-like diet quality of both groups were low thus showed no significant correlation between the DASH diet quality and HT in the study population ( $>0.05)$, as did the status of mental emotional disorder ( $p>0.05$ ). However, age may be a cofactor in this study because the age differed significantly between the normal and hypertension group $(p<0.05)$. This study shows that there was no difference in dietary quality between HT and non HT group as well as there were no significant correlation between diet quality and mental emotional disorder with HT status albeit segregation by the age group.
\end{abstract}

Keywords: DASH, dietary quality, mental emotional disorder, hypertension

\section{INTRODUCTION}

Cardiovascular Disease (CVD) has been the main cause of death globally including in Indonesia. Based on the Non-Communicable Disease Report issued by WHO (2014), $82 \%$ of non-communicable diseases occured in middle and lower income countries, $37 \%$ of which are CVD. One risk factor of cardiovascular disease is hypertension or high blood pressure. Based on Indonesian Basic Health Research (MoH 2013), the incidence of hypertension whether in urban or rural was not much different $(26.1 \%$ in urban and $25.5 \%$ in rural), yet the prevalence of hypertension in women was higher $(28.8 \%)$ than in men $(22.8 \%)$ and was more prevalent in rural area. Therefore it is imperative to investigate the incidence of hypertension in women living in rural areas to curb the prevalence of cardiovascular disease in Indonesia.

Psychological stress is a sign of a condition that is adapted. Within the normal limits, stress will have a positive impact on a person's mentality, but prolonged stress will damage the body's functionality. Mental emotional disorders that begin with psychological stress may influence blood pressure. This influence can occur both chronically as coronary heart disease and acutely by triggering a heartbeat (Steptoe \& Kivimaki 2012). Rahajeng \& Tuminah (2009) reported that hypertension was more prevalent in groups with emotional stress than those without emotional stress.

Joint National Committee (JNC) recommends that Dietary Approach to Stop Hypertension (DASH) intervention is an effective mean to prevent hypertension and reduce blood pressure (JNC 2006). JNC provides dietary recommendations for hypertensive patients as various servings for a variety of foods in one day. The DASH principle is focusing into foods that are low in saturated fats, total fat, carbohydrates, cholesterol, sodium, high potassium, calcium, magnesium, and fiber with a detailed range of nutritional needs.

Various studies have proven that DASH diet improved blood pressure and gave impact to cardiovascular disease (Fung et al. 2008; Ridhwan et al. 2012; Harrington et al. 2013; Saneei et al. 2014). Rahadiyanti et al. (2015) developed a scoring system for the DASH-like diet in Indonesia, which measured the quality of diet from nine

\footnotetext{
"Corresponding Author: tel: +6285881898809, email: ikeutanziha@gmail.com
} 
components of nutrients, namely carbohydrates, proteins, total fat, saturated fat, fiber, sodium, potassium, sodium:potassium ratio, calcium, and magnesium. The scoring system helps monitor the diet quality of hypertensive patients. We have developed a new DASH-like diet assessment based on the Indonesian 2013 RDA method and development of this scoring system can be found on Rahadiyanti et al. (2015).

Hypertension as a main risk factor for CVD is prevalent amongst women in rural areas. It can occur due to external factors such as the diet quality that does not match the DASH pattern as well as internal factors such as mental emotional distress. Therefore, this study aimed to analyse the relationship between diet quality and the level of mental emotional disorders with the incidence of hypertension in women in rural areas.

\section{METHODS}

\section{Design, location, and time}

This study was a cross sectional study conducted in December 2017. Respondents in this study were participants of larger study titled "Healthy Diet Indicator, Fat and Salt Diet, Lipid Profile, and Hypertension Risk in Sundanese and Minangkabau Women in Rural Areas". The study location of this research is in rural areas of Pondok Bungur Village, Pondok Salam District, Purwakarta Regency, West Java, Indonesia.

\section{Sampling}

Adult women aged 35 -55 years old who were participated in the main study (Healthy Diet Indicator, Fat and Salt Diet, Lipid Profile, and Hypertension Risk in Sundanese and Minangkabau Women in Rural Areas) were recruited for this study. The calculation of minimum subject using the base prevalence approach to one group, hypertension. Based on the calculation formula Lwanga \& Lemeshow (1991), then the number of respondents for both population is determined based on the prevalence of hypertension. After that the number is multiplied by two to get a total blood pressure subjects of hypertension and normal. The inclusion criteria were female, 35-55 years old, indigenous people or have long lived in the study area, for hypertension in the category $\geq 140 / 90 \mathrm{mmHg}$ in two measurements, conducting a health check and are willing to be interviewed as respondents. While the exclusion criteria were women with arm circumference that are beyond the ability of a hypertension tool to measure (too fat), systolic blood pressure $>165$ $\mathrm{mmHg}$, pregnant women, and fasting. After blood pressure screening using the JNC (2006) category where hypertension is when the blood pressure $\geq 140 \mathrm{mmHg}$ for systolic blood pressure and $\geq 90 \mathrm{mmHg}$ for diastolic blood pressure; there were 75 subjects with hypertension and 75 with normal blood pressure. Health check status was done to ensure that the respondent is truly willing to be the respondent who follows all stages of research in the main research. Health check was held by assessing anthropometric parameter such as weight and height (those variables were used by another report research), bringing the total sample to 73 normal and 73 hypertension. In this study, re-screening was carried out by reviewing the completeness of the questionnaire answers by the subjects, so that the final total was 71 normal and 72 hypertensive. This study has received an ethical feasibility letter which is included in the main study of the Ethics Commission for Health Research, Faculty of Public Health, Diponegoro University Number 259/EC/ FKM/2017.

\section{Data collection}

Structured questionnaires were used to collect socio-economic data (age, knowledge, years of education, and poverty status). Knowledge assessment used ten true/false questions about factors that affect hypertension. Data for diet quality was collected with $2 \times 24$ hours food recall. The Self Reporting Questionnaire (SRQ) 20 questionnaire was used to collect data on mental emotional disorders. SRQ 20 were developed by WHO in 1994 (Beusenberg \& Orley 1994) and was used by Indonesian Basic Health Research in 2007, 2010 and 2013 to determine the variables of emotional mental disorder of Indonesian (MoH 2013; MoH 2010; MoH 2013). This type of questionnaire assessed the risk of emotional mental disorder when subject affirmed more than 6 questions. It means subject should consult mental health service to diagnose and treat their suspected mental disorder. While for blood pressure measurement, standard automatic blood pressure monitor were utilized under the Omron ${ }^{\circledR}$ brand name.

\section{Data analysis}

Data on food consumption was processed with Nutrisurvey software. For food that has no standard food ingredients, dominant food ingredients were used from conventional recipe. After the food consumption data was processed, it was calculated according to the DASH-like diet component (Table 1). The target component of nutrients in the DASH diet referred to Rahadiyanti et al. (2015) and JNC (2006), where the need was adapted based on the Recommen-the need was 
adapted based on the Recommended Dietary Allowance (RDA) according to Ministry of Health Regulation number 41 concerning Balanced $\mathrm{Nu}$ trition Guidelines and other literatures (Table 1).

DASH-like diet is a collection of nutritional target values recommended by JNC (2006) to prevent hypertension, but the target of these nutrients has been adjusted to the nutritional adequacy of the Indonesian people and the distribution value in this study population. This concept of assessment follows previous research based on Rahadiyanti et al. (2015). Nutritional advice to prevent hypertension has a good, moderate and bad target value $(1 ; 0.5 ; 0)$. The "good" value if the respondent's intake meets the required nutritional value target, the "moderate" value is a range that is adjusted to certain references such as the RDA and the distribution value of the study population, while the "bad" value if the target value in the good and moderate categories is not fulfilled. These values are then accumulated into a diet quality score with 2 categories: good diet quality $(\geq 4.5)$ and poor diet quality $(<4)$.

The mental emotional disorder status assessment is divided into 2 categories according to $\mathrm{WHO}$, if affirmative response is given to more than 6 questions, the subject is categorized as having a mental emotional disorder. Data analysis was carried out using distribution data, ChiSquare test and Mann-Whitney difference test.

\section{RESULTS AND DISCUSSION}

Pressure and hypertension status in the study population is reflected in Table 2, respondents with normal blood pressure was $49.65 \%$ and $50.35 \%$ was with hypertension. The age group was divided into middle-aged adults (35-44 years), and late adults (45-65 years) with the late adult subjects (45-55 years) had more hypertensive subjects while the middle-aged (35-44 years) had more subjects with normal blood pressure (53 people). Both the normal and hypertensive groups had at least enough knowledge regarding factors related to hypertension (normal 54.93\%, hypertension $55.56 \%$ ), had completed more than six years of education (normal $80.28 \%$, hypertension $73.61 \%$ ), and living above the poverty line (normal $81.69 \%$, hypertension $81.94 \%$ ) (poverty line threshold citation needed based on Purwakarta's poverty line in 2017 IDR 325,607.00) (BPS 2019).

Some socio-economic variables such as age (Rahajeng \& Tuminah 2009; Fitria 2016; Indrawati 2009; Julianty 2010), knowledge (Tarigan et al. 2018; Wahyuni \& Susilowati 2018), education (Rahajeng \& Tuminah 2009; Fitria 2016; Indrawati 2009; Julianty 2010), and poverty status (Julianty 2010) have been established as a strong predictor for incidence of hypertension in several regions in Indonesia. However, the results of this

Table 1. Scoring of DASH-like diet

\begin{tabular}{|c|c|c|c|c|c|}
\hline Nutrient & $\begin{array}{l}\text { Score } 1 \\
\text { (Good) }\end{array}$ & $\begin{array}{l}\text { Score } 0.5 \\
\text { (Moderate) }\end{array}$ & $\begin{array}{l}\text { Score } 0 \\
(\mathrm{Bad})\end{array}$ & $\begin{array}{c}\text { DASH } \\
\text { target } \\
(\text { JNC 2006) }\end{array}$ & Reference \\
\hline $\begin{array}{l}\text { Carbohydrate } \\
(\% \text { total energy) }\end{array}$ & $\leq 40$ & $>40$ to $\leq 60$ & $>60$ & 55 & $\begin{array}{l}\text { Hardinsyah and Riyadi (2013) } \\
(40-60 \%)\end{array}$ \\
\hline $\begin{array}{l}\text { Protein } \\
\text { (\% total energy) }\end{array}$ & $\geq 18$ & $\geq 5$ to $<18$ & $<5$ & 18 & $\begin{array}{l}\text { Hardinsyah and Riyadi (2013) } \\
(5-15 \%)\end{array}$ \\
\hline $\begin{array}{l}\text { Fat } \\
\text { (\% total energy) }\end{array}$ & $\leq 27$ & $>27$ to $\leq 35$ & $>35$ & 27 & $\begin{array}{l}\text { Hardinsyah and Riyadi (2013) } \\
(25-35 \%)\end{array}$ \\
\hline $\begin{array}{l}\text { Saturated fat } \\
(\% \text { total energy) }\end{array}$ & $\leq 6$ & $>6$ to $\leq 15$ & $>15$ & 6 & $\begin{array}{l}\text { HEI } 2005 \text { (7-15\%) (Perdana } \\
\text { 2014) }\end{array}$ \\
\hline Fiber $(\mathrm{g})$ & $\geq 30$ & $\geq 28$ to $<30$ & $<28$ & 30 & $\begin{array}{l}\text { RDA } 2013 \text { (women aged 30- } \\
49 \text { and 50-64 target:30 and 28) }\end{array}$ \\
\hline Sodium (mg) & $\leq 1300$ & $>1300$ to $\leq 1500$ & $>1500$ & 2300 & $\begin{array}{l}\text { RDA } 2013 \text { ( women aged 30- } \\
49 \text { and 50-64 target: } 1500 \text { and } \\
1300 \text { ) }\end{array}$ \\
\hline $\mathrm{Na}: \mathrm{K}$ ratio & $<0.49$ & $\geq 0.49$ to $\leq 0.57$ & $>0.57$ & - & $\begin{array}{l}\text { Drewnoski }(2012) \\
\text { (based on US DRI }<0.49 \text { and } \\
\text { WHO }>0.57 \text { ) }\end{array}$ \\
\hline Calcium (mg) & $\geq 1250$ & $\geq 232.60$ to $<1250$ & $<232.60$ & 1250 & median 323.64 \\
\hline $\begin{array}{l}\text { Magnesium } \\
(\mathrm{mg})\end{array}$ & $\geq 500$ & $\geq 174.45$ to $<500$ & $<174.45$ & 500 & median 189.78 \\
\hline
\end{tabular}

HEI: Healthy Eating Index, RDA: Reccomendation Dietary Allowance 
Table 2. Differences in socio-economic characteristics according to hypertension status

\begin{tabular}{|c|c|c|c|c|c|}
\hline \multirow{2}{*}{ Variable } & \multicolumn{2}{|c|}{ Normal $(n=71)$} & \multicolumn{2}{|c|}{ Hypertension $(n=72)$} & \multirow{2}{*}{$\mathrm{p}^{*}$} \\
\hline & $\mathrm{n}$ & $\%$ & $\mathrm{n}$ & $\%$ & \\
\hline \multicolumn{6}{|l|}{ Age (years) } \\
\hline Middle-aged adults (35-44) & 53 & 74.6 & 37 & 48.6 & \multirow[t]{2}{*}{$0.001^{*}$} \\
\hline Late adults $(45-55)$ & 18 & 25.4 & 35 & 51.4 & \\
\hline \multicolumn{6}{|l|}{ Knowledge } \\
\hline Lack $(<6$, Quartile 1$)$ & 18 & 25.4 & 17 & 23.6 & \multirow{3}{*}{0.966} \\
\hline Enough $(6-8)$ & 39 & 54.9 & 40 & 55.6 & \\
\hline Good $(>8$, Quartile 3$)$ & 14 & 19.7 & 15 & 20.8 & \\
\hline Years of education (years) & & & & & 0.344 \\
\hline Not completed in primary school $(<6)$ & 14 & 19.7 & 19 & 26.4 & \\
\hline Completed in primary school $(>6)$ & 57 & 80.3 & 53 & 73.6 & \\
\hline Poverty status (IDR/capita/month) & & & & & 0.969 \\
\hline Under the poverty line & 13 & 18.3 & 13 & 18.1 & \\
\hline Above the poverty line & 58 & 81.7 & 59 & 81.9 & \\
\hline
\end{tabular}

*Chi-square test significant in $\mathrm{p}<0.05$

study indicate that there were no significant relationships between variables such as knowledge, length of education, and poverty status on hypertension status, except for age group.

These results were supported by Angkawijaya et al. (2016) study which states that knowledge was not significantly related to the occurrence of hypertension. Rahajeng \& Tuminah (2009) stated that expenditure levels per capita were not related to the incidence of hypertension, as well as Indrawati et al. (2009) revealed that economic status was not a risk factor for hypertension. Busingye et al. (2014) explained that the relationship of economic status with hypertension in rural areas in middle and lower income countries varied depending on the geographical location. Geographical location affects the pattern of society acting in daily life, increase wealth and urbanization affects lifestyle, diet, and obesity, thereby increasing the risk of hypertension in all circles (Colhoun et al. 1998; Lima et al. 2013).

In addition, Table 2 showed that age affects the incidence of hypertension $(p<0.05)$ with the late adults group was more at risk than the middle-age group. OR=3.113;95\% CI:1.53-6.31 . Increasing age in middle-aged adult women in this study (35-44 years old) towards late adulthood (45-55 years old) may indicate the present of biological changes such as menopause. In premenopause, women started to lose their estrogen hormone gradually which protects blood vessels from damage. In addition ageing also increases sympathetic activation and risk of depression in women (Lima et al. 2013).

The quality of the DASH-like diet, as an independent variable, was used to examine the relationship between the incidence of hypertension and the quality of diet. Table 3 shows that there was no relationship between the quality of the diet based on the DASH-like diet and the incidence of hypertension $(\mathrm{p} \geq 0.05)$.

Further analysis segregated by age groups using Chi Square multi-table with age as a control variable also showed no relationship between diet quality and hypertension status. Breakdown of nutrient intake in the two groups is presented in Table 4, difference tests showed that there was no difference in nutrient intake in the hypertension and normal blood pressure groups in all components of nutrients assessed on the DASHlike diet $(\mathrm{p} \geq 0.05)$.

Harrington et al. (2013) reported that adherence to a diet based on the recommended DASH diet can reduce blood pressure and the results of a systematic review by Saneei et al. (2014) also explained that the DASH diet can reduce blood pressure, both in systolic and diastolic. Our study found that the quality of the DASH-like diet in both groups were low, thus it can not prevent hypertension in the hypertension

Table 3. Relationship of diet quality with hypertension status

\begin{tabular}{lcccccccc}
\hline \multirow{2}{*}{ Diet quality } & \multicolumn{2}{c}{ Normal } & \multicolumn{2}{c}{ Hypertension } & \multirow{2}{*}{ OR } & \multirow{2}{*}{$95 \%$ CI } & $\mathrm{p}^{*}$ \\
\cline { 2 - 5 } & $\mathrm{n}$ & $\%$ & $\mathrm{n}$ & $\%$ & & & \multirow{2}{*}{0.472} \\
Good & 13 & 18.3 & 10 & 13.9 & \multirow{2}{*}{1.390} & $0.566-3.414$ & 0.472 \\
Lack & 58 & 81.7 & 62 & 86.1 & &
\end{tabular}

*Chi-square test significant in $\mathrm{p}<0.05$ 
Table 4. Different test of components of DASH-like diet based on the category of hypertension

\begin{tabular}{lccccc}
\hline \multirow{2}{*}{ Component of DASH-like diet } & \multicolumn{2}{c}{ Normal $(\mathrm{n}=71)$} & \multicolumn{2}{c}{ Hypertension $(\mathrm{n}=72)$} & \multirow{2}{*}{ * } \\
& Mean & SD & Mean & SD & \\
\hline Carbohydrate (\% total energy) & 54.2 & 9.2 & 56.3 & 13.3 & 0.286 \\
Protein (\% total energy ) & 13.9 & 3.8 & 13.3 & 4.4 & 0.143 \\
Fat (\% total energy) & 31.0 & 9.8 & 31.9 & 10.9 & 0.881 \\
Saturated fat (\% total energy) & 15.3 & 6.3 & 15.45 & 7.2 & 0.704 \\
Fiber (g) & 7.2 & 3.6 & 7.2 & 3.6 & 0.875 \\
Sodium (mg) & 1232.1 & 1711.4 & 1048.8 & 986.5 & 0.522 \\
Na:K ratio & 1.7 & 6.1 & 1.0 & 0.9 & 0.907 \\
Calcium (mg) & 359.34 & 376.0 & 288.8 & 260.7 & 0.156 \\
Magnesium (mg) & 192.3 & 70.9 & 187.3 & 97.1 & 0.359 \\
\hline
\end{tabular}

*Mann Whitney test significant in $\mathrm{p}<0.05$; SD: Standar Deviaton

group. Breakdown of nutritional intake showed that hypertensive groups had lower calcium intake, despite the calcium consumption in both hypertension and normal groups was still far from the calcium adequacy rate of $1250 \mathrm{mg}$.

Jayati et al. (2014) found that low calcium intake was influenced by low food preferences consuming fruits and animal foods, but higher in vegetables. Mierlo et al. (2006) stated that calcium supplementation compared with dairy intake was associated with blood pressure reduction. Dickinson et al. (2006) also mentioned that calcium has an effect on hypertensive patients both in systole and diastole. Low calcium intake will increase the concentration of intracellular calcium. This event results in an increase of 1.25-vitamin D3 and parathyroid hormone which causes calcium influx into smooth muscle cells and vascular resistance (Kris-Etherton et al. 2009). Other mechanisms show that peptides derived from milk protein, especially in fermented products function which can reduce blood pressure. The DASH tri- al found high consumption of fruits, vegetables and fiber in 8 weeks; 3 servings of low-fat processed milk per day; low total fat and saturated fat can reduce systolic and diastolic blood pressure by 5.5 and $3 \mathrm{mmHg}$ higher than the diet of the control group. Fruit and vegetable diets without the presence of processed dairy products only reduces about half of the results of DASH diet (Mahan et al. 2012).

Result also show that the fiber and magnesium intake of our respondents did not meet the needs in all groups. Svetkey et al. (1999) showed that diets with a variety of nutrients in the DASH diet have more influence on blood pressure reduction than diets with certain types of food. Conlin et al. (2000) also stated that a combination of high-vegetable, high-fruit, low-fat, and low-sugar diets is more influential on blood pressure than just a diet high in vegetables and fruits. This shows that blood pressure can be intervened with a combination of nutrients rather than just focusing on certain nutritional groups.

The main independent variables other than diet quality from this study were mental emotional distress status measured by SRQ-20. Mental emotional disorders are one of the internal factors that can affect a person's hypertension status, relationship between mental emotional disorders and hypertension status is shown in Table 5. Table 5 shows that there was no relationship between stress or mental emotional disorders with the incidence of hypertension in the study respondents ( $p \geq 0.05$ ), further segregation by age group through multi-table Chi-Square test $(p \geq 0.05)$ also showed non significant result.

Each SRQ-20 questions was analysed further to find out the differences in responses from normal and hypertensive groups to questions of emotional mental disorders (Table 6). Table 6 shows no significant difference between the number of respondents in the normal blood pressure and hypertension groups in each question $(p \geq 0.05)$, except in question regarding stomach discomfort $(\mathrm{p}<0.05)$.

Table 5. Relationship between mental emotional disorders and hypertension status

\begin{tabular}{lcccccccc}
\hline \multirow{2}{*}{ Status emotional mental disorder } & \multicolumn{2}{c}{ Normal } & \multicolumn{2}{c}{ Hypertension } & \multirow{2}{*}{ OR } & \multirow{2}{*}{$95 \%$ CI } & $\mathrm{p}^{*}$ \\
\cline { 2 - 5 } & $\mathrm{n}$ & $\%$ & $\mathrm{n}$ & $\%$ & & & \\
\hline Without mental emotional disorder & 35 & 49.3 & 36 & 50.0 & & 0.972 & $0.505-1.873$ & 0.933 \\
With mental emotional disorder & 36 & 50.7 & 36 & 50.0 & & \\
\hline
\end{tabular}

${ }^{*}$ Chi-square test significant in $\mathrm{p}<0.05$ 
Islami et al.

Table 6. Components of SRQ question based on the category of hypertension

\begin{tabular}{lccccc}
\hline \multirow{2}{*}{\multicolumn{1}{c}{ Item }} & \multicolumn{2}{c}{ Normal } & \multicolumn{2}{c}{ Hypertension } & \multirow{2}{*}{$\mathrm{p}^{*}$} \\
\cline { 2 - 5 } & $\mathrm{n}$ & $\%$ & $\mathrm{n}$ & $\%$ & \\
\hline You often suffer from headaches? & 50 & 70.4 & 55 & 76.4 & 0.419 \\
You don't have appetite? & 36 & 50.7 & 38 & 52.8 & 0.804 \\
You have trouble sleeping? & 34 & 47.9 & 40 & 55.6 & 0.359 \\
You are easily scared? & 25 & 35.2 & 30 & 41.7 & 0.428 \\
You feel tense, anxious or worried? & 35 & 49.3 & 35 & 48.6 & 0.935 \\
Your hands tremble? & 18 & 25.4 & 25 & 34.7 & 0.222 \\
Your digestion is impaired / bad? & 18 & 25.4 & 24 & 33.3 & 0.295 \\
You are hard to think clearly? & 25 & 35.2 & 27 & 37.5 & 0.776 \\
You feel unhappy? & 25 & 35.2 & 18 & 25.0 & 0.186 \\
You cry more often? & 17 & 23.9 & 25 & 34.7 & 0.157 \\
You find it difficult to enjoy daily activities? & 18 & 25.4 & 29 & 40.3 & 0.057 \\
You are difficult to make decisions? & 24 & 33.8 & 25 & 34.7 & 0.908 \\
Your daily work is interrupted? & 19 & 26.8 & 18 & 25.0 & 0.811 \\
You are not able to do useful things in life? & 20 & 28.2 & 19 & 26.4 & 0.813 \\
You lose interest in various things? & 18 & 25.4 & 26 & 36.1 & 0.163 \\
You feel worthless? & 16 & 22.5 & 24 & 33.3 & 0.150 \\
You have the mind to end life? & 5 & 7.0 & 9 & 12.5 & 0.272 \\
You feel tired all the time? & 26 & 36.6 & 29 & 40.3 & 0.653 \\
You experience discomfort in the stomach? & 22 & 31.0 & 34 & 47.2 & $0.047 *$ \\
You get tired easily? & 34 & 47.9 & 36 & 50.0 & 0.801 \\
\hline *Independent T-test for hypertension category significant in $\mathrm{p}<0.05$ & & & & \\
& & & & &
\end{tabular}

Table 7. Determinant of hypertension in hypertensive women

\begin{tabular}{lccc}
\hline \multicolumn{1}{c}{ Variable } & $\mathrm{p}^{*}$ & OR & $95 \% \mathrm{CI}$ \\
\hline Diet quality status & 0.803 & 1.127 & $0.440-2.890$ \\
Mental emotional disorder & 0.953 & 1.021 & $0.515-2.021$ \\
Poverty & 0.945 & 1.032 & $0.425-2.508$ \\
Age & 0.002 & 3.075 & $1.504-6.287$ \\
\hline
\end{tabular}

*Logistic regression test significant in $\mathrm{p}<0.05$

Cross sectional data analysis in Indonesian Basic Health Research in 2013 showed that although there was a relationship between stress or mental emotional disorders with hypertension, the relationship was very small, OR approached 1 (Idaiani \& Wahyuni 2016). Malonda et al. (2012) through a case-control study revealed that there was no relationship between stress and hypertension in the elderly. In contrast to prospective cohort studies conducted by Rahajeng et al. (2016) that those who consumed high sodium and experienced stress were found to suffer from hypertension earlier than those without stress. This may indicate that continuous and chronic distress may lead to increase in blood pressure, but not a short period stress.
There were three weaknesses of this study. First, this study didn't explain whether the hypertensive subjects consumed blood pressure lowering drugs. Secondly, despite findings that the sodium intake among hypertensive and normal group was under $2300 \mathrm{mg}$, this study didn't measure natrium intake from added-salt in dishes, for the most part sodium intake is only obtained from food. Last, the measurement of mental emotional disorders is only assessed in a short time as long as there are symptoms in the last 30 days. Thus it tent stress that will damage the body's functional mechanism. The pituitary adrenal Hypothalamo Axis (HPA) triggered by chronic stress causes the release of adrenal hormones, which when continuously produced will activate changes in the HPA 
axis. This change causes an increase in blood pressure, although there are some opinions that state this is uncertain (Idaiani \& Wahyuni 2016).

From the regression test above, age was the only variable that affects hypertension status in research population. Therefore, the cause of hypertension in this study is the age of the respondents, ageing which may relate to pre menopause or menopausal status.

\section{CONCLUSION}

Research showed that the DASH diet like quality of both groups were low, there was no relationship between the quality of the diet of women in rural areas with their hypertension status. Likewise with mental emotional stress status, there was no relationship between mental and emotional disorders with hypertension status in adult women in rural areas in the study population. Age is a factor that can influence the incidence of hypertension in the study population.

Further research is needed to provide more comprehensive information on the relationship of diet quality through various perspectives of the DASH diet and on the relationship between emotional mental disorders and hypertension using different research design such as whether the hypertension population has made changes in diet and lifestyle, finding out about menopausal conditions and using higher research designs such as case control and cohort.

\section{ACKNOWLEDGEMENT}

Our gratitude goes to the Research Team of "Healthy Diet Indicator, Fat and Salt Diet, Lipid Profile, and Risk of Hypertension in Sundanese and Minangkabau Women in Rural Areas" who have provided the opportunity to collaborate and the Neys-van Hoogstraten Foundation (NHF) for financial assistance grant in the main research. The authors have no conflict of interest.

\section{REFERENCES}

Angkawijaya AA, Pangemanan JM, Siagian IE. 2016. Hubungan tingkat pengetahuan masyarakat dengan tindakan pencegahan hipertensi di desa Motoboi Kecil Kecamatan Kotamobagu Selatan. JKKT 4(1):73-77.

Beusenberg M, Orley J. 1994. A User's Guide to the Self Reporting Questionnaire (SRQ). Division of Mental Health. WHO: Geneva.

[BPS] Badan Pusat Statistik. 2019. Jumlah dan Persentase Penduduk Miskin, Indeks Ke- dalaman Kemiskinan (P1), Indeks Keparahan Kemiskinan (P2), dan Garis Kemiskinan Menurut Kabupaten/Kota di Jawa Barat Tahun 2017-2018. https://bandungkota.bps.go.id/statictable/2019/01/04/180/ tabel-kemiskinan-kabupaten-kota-diprovinsi-jawa-barat-tahun-2017-2018. html. [Accessed 15 January 2019].

Busingye D, Arabshahi S, Subasinghe AK, Evans RG, Riddell MA, Thrift AG. 2014. Do the socio-economic and hypertension gradients in rural populations of lowand middle-income countries differ by geographical region? A systematic review and metaanalysis. Int J Epidemiol 43(5): 1563-1577.

Colhoun HM, Hemingway H, Poulter NR. 1998. Socio-economic status and blood pressure: An overview analysis. J Hum Hypertens 12(2):91-110.

Conlin PR, Chow D, Miller ER, Svetkey LP, Lin PH, Harsha DW, Moore TJ, Sacks FM, Appel LJ. 2000. The effect of dietary patterns on blood pressure control in hypertensive patients: Results from the dietary approaches to stop hypertension (DASH) trial. Am J Hypertens 13(9):949-955.

Dickinson HO, Mason JM, Nicolson DJ, Campbell F, Beyer FR, Cook JV, Williams B, Ford GA. 2006. Lifestyle interventions to reduce raised blood pressure: A systematic review of randomized controlled trials. J Hypertens 24(2):215-223.

Drewnowski A, Maillot M, Rehm C. 2012. Reducing the sodium-potassium ratio in the US diet: A challenge for public health. Am J Clin Nutr 96:439-444.

Fitria E. 2016. Karakteristik penderita hipertensi pada Ulee Kareng Kota Banda Aceh. Sel Jurnal Penelitian Kesehatan 3(2):64-70.

Fung TT, Chiuve SE, McCullough ML, Rexrode KM, Logroscino GL, Hu FB. 2008. Adherence to a DASH-style diet and risk of coronary heart disease and stroke in women. Arch Intern Med 168(7):713-720.

Hardinsyah, Riyadi H, Napitupulu V. 2012. Kecukupan energi, protein, lemak dan karbohidrat: WNPG 2004. Jakarta: Departemen Gizi FK UI.

Harrington JM, Fitzgerald AP, Kearny PM, McCarthy VJC, Madden J, Browne G, Dolan E, Perry J. 2013. DASH diet score and distribution of blood pressure in middleaged men and women. Am J Hypertens. 26(11):1311-1312.

Idaiani S, Wahyuni HS. 2015. Hubungan gangguan mental emosional dengan hipertensi 
pada penduduk Indonesia. Media Litbang Kes 26(3):137-144.

Indrawati L, Werdbasari A, Yuki AK. 2009. Hubungan pola kebiasaan diet makanan masyarakat miskin dengan kejadian hipertensi di Indonesia. Media Litbang Kes 19(4):174-184.

[JNC] Joint National Committee. 2006. Your Guide to Lowering Your Blood Pressure with DASH. London: NIH Publication.

Jayati LD, Madanijah S, Khomsan A. 2014. Pola konsumsi pangan, kebiasaan makan, dan densitas gizi pada masyarakat Kasepuhan Ciptagelar Jawa Barat. Penelitian Gizi dan Makanan 37(1):33-42.

Julianty P. 2010. Faktor-Faktor yang Memengaruhi Terjadinya Hipertensi di Daerah Perkotaan (Analisis Data Riskesdas 2007). Gizi Indon. 33(1):59-66.

Kris-Etherton PM, Grieger JA, Hilpert KF, West SG. 2009. Milk products, dietary patterns and blood pressure management. J Am Coll Nutr 28(sup1):103S-119S.

Kumar V, Abbas AK, Fausto N. 2005. Hypertensive Vascular Disease. In: Robin and Cotran Pathologic Basis of Disease, $7^{\text {th }} \mathrm{Ed}$. Philadelpia: Elsevier Saunders.

Lima R, Wofford M, Reckelhoff JF. 2013. Hypertension in Postmenopausal Women 14(3):254-260.

Lwanga SK, Lemeshow S. 1991. Sample Size Determination in Health Studies. World Health Organization. Geneva: WHO.

Mahan LK, Escott-Stump S, Raymond JL, Krause MV. 2012. Krause's Food and Nutrition Care Process. St. Louis: Saunders.

Malonda NS. 2010. Pola makan dan konsumsi alkohol sebagai faktor risiko hipertensi pada lansia di Kota Tomohon Sulawesi Utara. JGKI 8(4):202-212.

Mierlo LAJ, Arends LR, Streppel MT, Zeegers MPA, Kok FJ, Grobbee DE, Geleinjse JM. 2006. Blood pressure response to calcium supplementation: A Meta-analysis of randomized controlled trials. J Hum Hypertens 20(8):571-580.

[MoH] Ministry of Health. 2007. Indonesian Basic Health Research (Riskesdas) 2007. Jakarta: Ministry of Health Republic of Indonesia.

[MoH] Ministry of Health. 2010. Indonesian Basic Health Research (Riskesdas) 2010. Jakarta: Ministry of Health Republic of Indonesia.
[MoH] Ministry of Health. 2013. Indonesian Basic Health Research (Riskesdas) 2013. Jakarta: Ministry of Health Indonesia.

Perdana SM. 2014. Alternatif indeks gizi seimbang untuk penilaian mutu gizi konsumsi pangan wanita dewasa Indonesia. J Gizi Pangan. 9(1):43-50.

Rahadiyanti A, Setianto BY, Purba MB. 2015. Asupan makan DASH-like diet untuk mencegah risiko hipertensi pada wanita prediabetes. J Gizi Klinik Ind. 11:115-125.

Rahajeng E, Kristanti D, Kusumawardani N. 2016. Perbedaan laju kecepatan terjadinya hipertensi menurut konsumsi natrium: studi kohort prospektif di Kota Bogor, Jawa Barat, Indonesia. Penelitian Gizi dan Makanan 39(1):45-53.

Rahajeng E, Tuminah S. 2009. Prevalensi hipertensi dan determinannya di Indonesia. Majalah Kedokteran Indonesia 59(12):580587.

Ridhwan H, Heryudarini, Setiawan B, Effendi I. 2012. An efficacy of the Indonesian modified dash diet on reducing body weight and blood pressure. Abstract. Nutr Diet 69(1):121.

Saneei P, Salehi-Abargouei A, Esmaillzadeh A, Azadbakt L. 2014. Influence of dietary approaches to stop hypertension (DASH) diet on blood pressure: a systematic review and meta-analysis on randomized controlled trials. Accepted Manuscript. Nutr Metab Cardiovasc Dis 24(12):1253-1261. doi:10.1016/j.numecd.2014.06.008.

Steptoe A, Kivimaki M. 2012. Stress and Cardiovascular Disease. Nat Rev Cardiol 9(6):360-370.

Svetkey LP, Simons-Morton D, Vollmer WM, Appel LJ, Conlin PR, Ryan DH, Ard J, Kennedy BM. 1999. Subgroup Analysis of the Dietary Approaches to Stop Hypertension (DASH) randomized clinical trial. Arch Intern Med 159(3):285-293.

Tarigan AR, Lubis Z, Syarifah. 2018. Dukungan keluarga terhadap diet hipertensi di desa hulu Kecamatan Pancur Batu Tahun 2016. Jurnal Kesehatan 11(1):8-16.

Wahyuni, Susilowati T. 2018. Pola makan dan jenis kelamin dan hubungan pengetahuan terhadap kejadian hipertensi di kalurahan sambung macan sragen. Gaster 16(1):7382.

[WHO] World Health Organization. 2014. Non Communicable Disease Country Profiles 2014. Geneva: WHO. 